\title{
Accessing the attitudes of successors in dairy farms toward educational tourism
}

\author{
Y. Ohe \\ Department of Food and Resource Economics, Chiba University, Japan
}

\begin{abstract}
Educational activities provided by farmers have recently been gaining attention and enabling consumers to learn about food, life and rural heritage. This paper reports the attitudes of the next-generation successors of Educational Dairy Farms (EDF) who are now working on-farm, in comparison with their counterparts working on ordinary dairy farms in Japan, as determined by questionnaire surveys. First, the main findings were that the EDF successors tended to have wider job experience, and longer and more varied training experience across the country and/or abroad than their counterparts in ordinary dairy farms. This means that EDF successors have both a wider perspective and more extensive human networks from social learning opportunities. Second, EDF successors gained high psychological rewards and strengthened their identity as a dairy farmer from the educational activity of the farm, including more self-confidence and pride as a dairy farmer. Third, most successors, however, did not consider the educational service to be economically viable. Thus, in the long term, it will be necessary to levy a service charge to make the educational activity viable. Quality improvement was considered to be a necessary measure for this purpose.
\end{abstract}

Keywords: educational tourism, rural tourism, dairy farm, farm tourism, agritourism.

\section{Introduction}

Educational activities provided by farmers are gaining popularity and are included in the category of experience-oriented tourism. Examples of such activities that have been already implemented include the Farming And Countryside Education (FACE) program in the UK [1], (for more recent 
developments [2], Ferme Pédagogique in France, Fattorie Didattiche in EmiliaRomagna in Italy [3], children's gardening in the USA [4] and educational dairy farms (EDFs) in Japan [5]). Through farm visits, children and adult consumers can learn how food is produced from land and livestock, and what jobs are performed for this production. Especially in dairy farming, the presence of livestock enables visitors to realize the connection between life and food - a fundamental link that is related to the meaning of life but is often forgotten daily.

In this context, it is expected that the educational activity provided by farmers can create a new social role for dairy farming and might eventually generate a new income source to counter stagnant demand for dairy products. So far, however, such educational activities have not become economically viable [6]. Thus, how to attain viability is a crucial issue for the development of educational tourism in agriculture. Because educational tourism in agriculture is a relatively newly emerging topic, this issue has been seldom addressed except for a bunch of studies by [6-8], which examined the attitudes of the EDF operators toward the educational activity and disclosed their reasons for becoming an EDF, in addition their satisfaction with the educational service and issues for future development.

Because EDFs mostly comprise family farms, it is essential to clarify how the next generation of successors views the educational activity in terms of its sustainable development. As yet, however, this issue has not been explored. From this perspective, this paper examines the attitudes of farm successors who have already taken a full time job on-farm toward the educational activity by focusing on EDFs in Japan, which provide one of the most well-organized educational services in agriculture.

To achieve this aim and following on from previous studies, this paper has investigated the experience and views of EDF operators of the younger generation toward the educational activity on the basis of data collected by questionnaire surveys directed toward the successors of both EDFs and ordinary dairy farms. To clarify the point, I have compared the attributes of respondents between EDFs and ordinary dairy farms. Finally, I discuss policy implications regarding the viability of educational tourism in agriculture.

\section{Trend of Educational Dairy Farms}

\subsection{Outline of the program of Educational Dairy Farms}

The EDF program was established in 2000 by the Japan Dairy Council, which is a national organization that conducts promotional activities for dairy farms. The purpose of this program is to provide accurate information on what dairy farms do in order to improve the public's understanding of the role of dairy farming in society. The aim of the EDF is not only to promote an open-door policy for the farmyard toward the general public, but also to enhance the educational value of dairy farming through teaching where milk comes from and the life of the milk cows on the farm. In this respect, the farmers' role is crucial and thus they are called facilitators in this program. For instance, when visitors experience milking, 
they learn that warm white milk comes from the udder of a cow, which is a simple fact, but is quite different from the cool milk in a carton in the refrigerator that they are used to drinking every day. A facilitator explains to visitors that 'white' milk is generated in the udder from 'red' blood, which symbolizes life, and that the same process also happens in humans. When visitors are lucky enough to come across the birth of a calf, they gain a lifelong impression of the meaning of life. The Council administers the certification for recognition as an EDF and, together with teachers, develops educational materials both to enhance the effects of this activity and to provide seminars to improve skills of facilitators. When the last survey was conducted in 2012, 309 farms were designated EDFs.

Interestingly, the number of visitors increased year on year to reach more than 880 thousand in 2009. Particularly, the number of visitors from April to September, i.e. summer time, increased more rapidly than that from October to March, i.e. winter time. Nevertheless, the number of visitors dropped suddenly in 2010 due to an outbreak of foot and mouth disease, which is highly contagious to cloven-hoofed animals such as cows and pigs. If it spreads, it has a devastating effect on the local livestock industry. Because of this outbreak, many operators closed their farms to visitors to reduce the risk of this disease. Fortunately, the drop in numbers did not last, and the number of visitors picked up again despite another disaster in March, 2011, when a gigantic earthquake hit northern Japan. As of the end of 2012 when the current questionnaire survey was conducted, the number of visitors had returned to $95 \%$ of the level in 2009 . It is expected that the demand for farm visits will increase in the future, along with a growing demand for experience-oriented tours in general.

\section{Data}

Data were collected by a questionnaire survey directed only toward EDFs that were mainly run by families to narrow data variation. Although the majority of EDFs are family farms, the EDF program also includes public ranches, ranches run by cooperatives and the dairy industry, college ranches and agricultural high schools. These types of non-family farm were not included in the present survey. The survey was implemented jointly with the Japan Dairy Council, which selected farms and is the founding body of this survey. The survey was sent by surface mail from the author's office to 248 farms and returned between September and December 2012. The response rate was 141 farms (56.8\%).

Over the same period, another questionnaire was distributed by surface mail to ordinary dairy farms through regional dairy cooperatives, which selected 470 mainly family-run farms across the country for comparison with the EFDs. The response rate was $48.5 \%$ (228 farms).

\section{Results}

\subsection{Attributes of respondents}

First, the attributes of all respondents were tabulated in order to compare them between respondents from ordinary dairy farms, termed "ordinary respondents" 
hereafter, and those from EDFs (Table 1). The average age of the ordinary respondents was younger than that of the EDF respondents. In this sense, the EDF respondents were more experienced than the ordinary respondents. Interestingly, the proportion of females was much higher, nearly $20 \%$, among EDF respondents than among ordinary respondents $(18.4 \%$ and $3.5 \%$, respectively). This fact indicates that female successors will play an important role in EDF activity.

Table 1: Respondents' attributes and dairy production.

\begin{tabular}{|c|c|c|c|c|}
\hline Item & \multicolumn{2}{c|}{ Ordinary dairy farm } & \multicolumn{2}{c|}{ EDF } \\
\hline Age on average & \multicolumn{2}{|c|}{34.5} & \multicolumn{2}{c|}{43.1} \\
\hline Age of starting farming & \multicolumn{2}{|c|}{23.9} & \multicolumn{2}{c|}{25.0} \\
\hline Sex & $\%$ & $\begin{array}{c}\text { No. } \\
\text { respondents }\end{array}$ & $\%$ & $\begin{array}{c}\text { No. } \\
\text { respondents }\end{array}$ \\
\hline Male & 94.7 & 216 & 78.0 & 110 \\
\hline Female & 3.5 & 8 & 18.4 & 26 \\
\hline No answer & 1.8 & 4 & 3.5 & 5 \\
\hline Total & 100.0 & 228 & 100.0 & 141 \\
\hline Item & Mean & No. & Mean & $\begin{array}{c}\text { No. } \\
\text { respondents }\end{array}$ \\
\hline responds \\
\hline Amount of milk production (t) & 400.6 & 202 & 561.2 & 131 \\
\hline No. milk cows (Holstein cow) & 55.1 & 221 & 72.4 & 133 \\
\hline Type of farm & $\%$ & No. & $\%$ & No. \\
\hline Family farm & respondents & $\%$ & respondents \\
\hline Corporate family farm & 91.2 & 208 & 70.9 & 100 \\
\hline Jointly run non-corporate farm & 5.7 & 13 & 17.0 & 24 \\
\hline Jointly run corporate farm & 0.0 & 0 & 0.7 & 1 \\
\hline Others & 0.4 & 1 & 3.5 & 5 \\
\hline No answer & 1.3 & 3 & 5.7 & 8 \\
\hline Total & 1.3 & 3 & 2.1 & 3 \\
\hline & 100.0 & 228 & 100.0 & 141 \\
\hline
\end{tabular}

Source: Questionnaire surveys completed by successors who had taken jobs on-farm at EDFs and ordinary dairy farms sent out between September and December 2012 by surface mail. The number of respondents was 141 of 248 EDFs (56.8\%) and 228 of 470 ordinary farms $(48.5 \%)$.

In terms of milk production, EDFs were larger. With respect to the type of management, the proportion of corporate family farms was higher among EDFs $(17 \%)$ than among ordinary farms, of which more than nine out of ten were noncorporate family farms.

Second, academic background, job history and job-training experience were compared between the two categories of respondents (Table 2). The proportion of those who finished university and graduate school was slightly higher among EDFs than among ordinary farms, and the EDF respondents had gained wider job experience before taking a job on their own farms. Put differently, the EDF respondents were less likely to take their jobs on their home farm directly after finishing school. Furthermore, the EDF respondents had more experience abroad 
and/or across the country in terms of their job-training experience in dairy; that is, over $70 \%$ of the EDF respondents had job-training experience, whereas $36 \%$ of the ordinary respondents had no job-training experience (Table 3). In terms of job-training abroad, more EDF respondents went to Europe, where farm activity tends to be more diversified than other areas, as compared with ordinary respondents ( $40 \%$ and $25 \%$, respectively). Furthermore, the EDF respondents tended to stay abroad for a longer period than the ordinary respondents. Another interesting difference between the two groups was observed in the content of the job-training; the EDF respondents were more eager to learn processing skills and skills related to the exchange with consumers, whereas the ordinary respondents were more inclined to learn dairy production skills.

Table 2: Academic background and jobs before farming.

\begin{tabular}{|c|c|c|c|c|}
\hline Item & \multicolumn{2}{c|}{ Ordinary dairy farm } & \multicolumn{2}{c}{ EDF } \\
\hline Academic background & $\%$ & $\begin{array}{c}\text { No. } \\
\text { respondents }\end{array}$ & $\%$ & $\begin{array}{c}\text { No. } \\
\text { respondents }\end{array}$ \\
\hline Jr High school & 1.8 & 4 & 0.0 & 0 \\
\hline High School & 30.7 & 70 & 27.0 & 38 \\
\hline Jr college/ Vocational school & 36.4 & 83 & 36.2 & 51 \\
\hline University & 28.5 & 65 & 32.6 & 46 \\
\hline Graduate school & 1.8 & 4 & 1.4 & 2 \\
\hline No answer & 0.9 & 2 & 2.8 & 4 \\
\hline Total & 100.0 & 228 & 100.0 & 141 \\
\hline Occupation before farm-job taking & $\%$ & No. & $\%$ & No. \\
\hline (multiple answers) & $\%$ & respondents & $\%$ & respondents \\
\hline Student & 47.8 & 109 & 39.0 & 55 \\
\hline Company employee & 25.4 & 58 & 24.1 & 34 \\
\hline Public-sector employee & 3.1 & 7 & 2.1 & 3 \\
\hline Teacher & 0.0 & 0 & 2.1 & 3 \\
\hline Agri. cooperative employee & 8.3 & 19 & 2.8 & 4 \\
\hline Self-employed & 0.9 & 2 & 5.7 & 8 \\
\hline No employment & 1.3 & 3 & 2.1 & 3 \\
\hline Others & 9.2 & 21 & 12.1 & 17 \\
\hline No answer & 4.4 & 10 & 9.9 & 14 \\
\hline Total & 100.4 & 229 & 100.0 & 141 \\
\hline
\end{tabular}

Source: As Table 1.

In short, as compared with the ordinary respondents, the EDF respondents ran larger farms of a more corporate nature with more female involvement, and had more active job-training experience as well as longer and more varied job experience. These facts indicate that the EDFs respondents had a wider perspective on dairy activities. Table 4 supports this indication, which contrasted the method of public relations (PR) used by the farm between the two groups of respondents. The EDF respondents were very active in promoting their farms through various channels from having their own website to publicity in magazines, whereas nearly $80 \%$ of the ordinary respondents did not carry out 
Table 3: Experience of job training in dairy farms abroad.

\begin{tabular}{|c|c|c|c|c|}
\hline Item & \multicolumn{2}{|c|}{ Ordinary dairy farm } & \multicolumn{2}{|r|}{ EDF } \\
\hline Place of training & $\%$ & $\begin{array}{c}\text { No. } \\
\text { respondents }\end{array}$ & $\%$ & $\begin{array}{c}\text { No. } \\
\text { respondents }\end{array}$ \\
\hline Only in the country & 49.1 & 112 & 39.0 & 55 \\
\hline Only abroad & 1.3 & 3 & 6.4 & 9 \\
\hline Domestic \& abroad & 11.8 & 27 & 26.2 & 37 \\
\hline No experience either & 36.0 & 82 & 24.1 & 34 \\
\hline No answer & 1.8 & 4 & 4.3 & 6 \\
\hline Total & 100.0 & 228 & 100.0 & 141 \\
\hline $\begin{array}{l}\text { Region of training abroad } \\
\text { (multiple answers) }\end{array}$ & $\%$ & $\begin{array}{c}\text { No. } \\
\text { respondents }\end{array}$ & $\%$ & $\begin{array}{c}\text { No. } \\
\text { respondents }\end{array}$ \\
\hline North America & 37.5 & 15 & 36.7 & 22 \\
\hline Europe & 25.0 & 10 & 40.0 & 24 \\
\hline Oceania & 17.5 & 7 & 18.3 & 11 \\
\hline Other & 7.5 & 3 & 5.0 & 3 \\
\hline No answer & 12.5 & 5 & 0.0 & 0 \\
\hline Total & 100.0 & 40 & 100.0 & 60 \\
\hline Period of training & $\%$ & $\begin{array}{c}\text { No. } \\
\text { respondents }\end{array}$ & $\%$ & $\begin{array}{c}\text { No. } \\
\text { respondents }\end{array}$ \\
\hline Les than three months & 47.1 & 16 & 44.9 & 22 \\
\hline 3 months -5 months & 2.9 & 1 & 4.1 & 2 \\
\hline 6 months- 11 months & 5.9 & 2 & 16.3 & 8 \\
\hline one-two years & 26.5 & 9 & 30.6 & 15 \\
\hline more than three years & 2.9 & 1 & 4.1 & 2 \\
\hline No answer & 17.6 & 6 & 0.0 & 0 \\
\hline Total & 102.9 & 35 & 100.0 & 49 \\
\hline Content of training (Multiple answers) & $\%$ & $\begin{array}{c}\text { No. } \\
\text { respondents }\end{array}$ & $\%$ & $\begin{array}{c}\text { No. } \\
\text { respondents }\end{array}$ \\
\hline Dairy production skills & 40.4 & 23 & 33.7 & 28 \\
\hline Dairy processing skills & 3.5 & 2 & 12.0 & 10 \\
\hline Management skills & 17.5 & 10 & 19.3 & 16 \\
\hline Exchange with consumers & 1.8 & 1 & 12.0 & 10 \\
\hline Exchange with farmers & 21.1 & 12 & 18.1 & 15 \\
\hline Other & 5.3 & 3 & 4.8 & 4 \\
\hline No answer & 10.5 & 6 & 0.0 & 0 \\
\hline Total & 100.0 & 57 & 100.0 & 83 \\
\hline
\end{tabular}

Source: As Table 1.

any PR activities. Although the majority of the ordinary respondents thought that they needed farm diversification, in reality they rarely had a chance to exchange directly with consumers (Table 5).

\section{Activity of the Educational Dairy Farm}

Here, I examined what the EDF respondents are doing, as well as the attitudes that they have, toward the educational activities of the farms. Table 6 shows the outcomes of EDF activity. There were large variances in the number of visitors and in the number of times that the educational activity was practiced. The 
Table 4: Public relations methods used by each farm (multiple answers).

\begin{tabular}{|c|c|c|c|c|}
\hline \multirow{2}{*}{ Item } & \multicolumn{2}{c|}{ Ordinary dairy farm } & \multicolumn{2}{|c|}{ EDF } \\
\cline { 2 - 5 } & $\%$ & $\begin{array}{c}\text { No. } \\
\text { respondents }\end{array}$ & $\%$ & $\begin{array}{c}\text { No. } \\
\text { respondents }\end{array}$ \\
\hline Holding own website & 2.1 & 5 & 19.5 & 43 \\
\hline Twitter/blog & 3.0 & 7 & 10.9 & 24 \\
\hline Facebook & 6.4 & 15 & 10.4 & 23 \\
\hline Distribution of fryer & 0.4 & 1 & 9.5 & 21 \\
\hline Publicity & 5.5 & 13 & 9.0 & 20 \\
\hline Nothing in particular & 78.0 & 184 & 33.0 & 73 \\
\hline Other & 3.4 & 8 & 7.2 & 16 \\
\hline No answer & 1.3 & 3 & 0.5 & 1 \\
\hline Total & 100.0 & 236 & 100.0 & 221 \\
\hline
\end{tabular}

Source: As Table 1.

Table 5: Attitude toward diversification (ordinary fairy farms).

\begin{tabular}{|c|c|c|}
\hline Necessity of farm diversification & $\%$ & $\begin{array}{c}\text { No. } \\
\text { respondents }\end{array}$ \\
\hline Think so & 18.4 & 42 \\
\hline Think so a little & 38.2 & 87 \\
\hline Do not think so much & 24.1 & 55 \\
\hline Do not think so & 14.0 & 32 \\
\hline Do not think so & 3.1 & 7 \\
\hline No answer & 2.2 & 5 \\
\hline Total & 100.0 & 228 \\
\hline Experience of exchange with consumers & $\%$ & No. \\
\hline No experience & 41.7 & 95 \\
\hline Once or twice a year & 43.0 & 98 \\
\hline Once a few months & 11.0 & 25 \\
\hline Once a month & 1.8 & 4 \\
\hline More than a few times a month & 0.9 & 2 \\
\hline No answer & 1.8 & 4 \\
\hline Total & 100.0 & 228 \\
\hline
\end{tabular}

Source: As Table 1.

number of visitors and number of times were roughly distributed around 100 visitors and 10 times, respectively.

Table 7 lists the reasons for starting the EDF activities, which were evaluated via a Likert scale ranging from 5 to 1 , indicating that the respondents agreed, slightly agreed, neither agreed nor disagreed, slightly disagreed, disagreed. The three reasons with the highest scores were 'to let consumers know what dairy farms do', 'as a community service', and 'to establish human networks', all three of which are not economic, but rather social reasons. Economic reasons, such as 
Table 6: Outcome of EDF activity.

\begin{tabular}{|c|c|c|}
\hline No. visitors & $\%$ & $\begin{array}{c}\text { No. } \\
\text { respondents }\end{array}$ \\
\hline-49 & 30.5 & 43.0 \\
\hline $50-99$ & 23.4 & 33.0 \\
\hline $100-299$ & 12.8 & 18.0 \\
\hline $300-499$ & 6.4 & 9.0 \\
\hline $500-999$ & 10.6 & 15.0 \\
\hline $1000-1999$ & 4.3 & 6.0 \\
\hline $2000-$ & 9.9 & 14 \\
\hline No answer & 2.1 & 3 \\
\hline Total & 100.0 & 141 \\
\hline of times receiving visitors & $\%$ & No. \\
\hline zero & 7.8 & 11 \\
\hline $1-10$ & 46.8 & 66 \\
\hline $11-30$ & 21.3 & 30 \\
\hline $31-50$ & 7.1 & 10 \\
\hline $51-100$ & 6.4 & 9 \\
\hline $100-$ & 8.5 & 12 \\
\hline No answer & 2.1 & 3 \\
\hline Total & 100.0 & 141 \\
\hline & & \\
\hline
\end{tabular}

Source: As Table 1.

'a new income source', were not scored highly. After performing the EDF activity, the respondents experienced various positive changes in themselves. The top three changes were 'increasing self-confidence and pride', 'enjoyment of exchange with consumers', and 'increasing awareness of playing a social role'; by contrast, changes in economic aspects, such as 'as a viable activity', 'as a mean of sales promotion for dairy products', and 'as a new income source', were not scored highly. These observations indicate that the EDF respondents have a wider perspective that enables them to look at emerging social roles and to build their self-confidence through the educational activity, which in itself has an educational effect on farmers.

Table 8 shows how the EDF operators view the educational activity. Currently, the majority of them offer the educational activity on a voluntary or cost-covering basis. By contrast, those who have considered the activity from an economic viewpoint, such as means of marketing or as a viable enterprise, accounted for only $20 \%$. In this respect, therefore, the EDF operators conduct the educational activity not as an economic, but as a social activity. Nevertheless, $40 \%$ of respondents expressed their intention to consider as the activity as an economic enterprise in the future. 
Table 7: Successors' attitudes toward EDF activity.

\begin{tabular}{|c|c|c|}
\hline $\begin{array}{c}\text { Reason for starting EDF } \\
\text { (5-scale evaluation) }\end{array}$ & Point & $\begin{array}{l}\text { No. } \\
\text { respondents }\end{array}$ \\
\hline Let consumers know what diary farms do & 4.4 & 136 \\
\hline As community service & 4.2 & 133 \\
\hline Making human network & 3.8 & 132 \\
\hline Enlargement of activity & 3.7 & 132 \\
\hline Wanted to do different from what has been done & 3.2 & 126 \\
\hline As evolution of open farm policy & 3.1 & 124 \\
\hline As a new income source & 2.8 & 127 \\
\hline As parents started EDF & 2.5 & 118 \\
\hline Wanted to do what was different from what parents did & 2.2 & 117 \\
\hline Other & 1.4 & 9 \\
\hline $\begin{array}{l}\text { Change in consciousness after EDF started } \\
\text { (5-scale evaluation) }\end{array}$ & Point & $\begin{array}{c}\text { No. } \\
\text { respondents }\end{array}$ \\
\hline Enhancement of self-confidence \& pride & 4.3 & 132 \\
\hline Enjoyment of exchange with consumers & 4.3 & 133 \\
\hline Increasing awareness of social role & 4.3 & 132 \\
\hline Connection with local community & 4.1 & 128 \\
\hline Revaluation of farm resource & 4.1 & 129 \\
\hline Enjoyment of teaching experience & 4.0 & 130 \\
\hline Enlargement of human network & 3.9 & 131 \\
\hline Discovery of new material for EDF & 3.9 & 130 \\
\hline As a viable activity & 2.7 & 126 \\
\hline As a mean of sales promotion for dairy products & 2.7 & 125 \\
\hline New income source & 2.7 & 124 \\
\hline Nothing in particular & 2.0 & 74 \\
\hline Other & 1.0 & 6 \\
\hline
\end{tabular}

Source: As Table 1.

There is no single answer regarding how the EDF operators should view the educational activity. Given the increasing demand for farm visits, it may be time to start gradually shifting the emphasis from a social activity to an economic activity. From this perspective, levying a fee will be essential to establish the economic viability of this service. Table 9 indicates the attitudes of the EDF respondents toward levying a service charge: one-third of respondents said no charge; about 30\% would charge for the whole service, which was followed $24.1 \%$ who were already making a partial charge. Thus, operators' attitudes are split into dichotomous views on charging. The lower part of Table 9 lists the respondents' views concerning measures toward implementing a charge for the educational services. The top measure was quality improvement, which was followed by PR activity, and financial assistance. 
Table 8: Attitudes toward EDF activity (present and future).

\begin{tabular}{|c|c|c|}
\hline Attitude toward EDF at present & $\%$ & $\begin{array}{c}\text { No. } \\
\text { respondents }\end{array}$ \\
\hline Voluntary & 28.4 & 40 \\
\hline Cost covering & 32.6 & 46 \\
\hline Means of marketing & 9.9 & 14 \\
\hline As a viable activity & 9.2 & 13 \\
\hline Nothing in particular & 11.3 & 16 \\
\hline Other & 7.8 & 11 \\
\hline No answer & 0.7 & 1 \\
\hline Total & 100.0 & 141 \\
\hline Attitude toward EDF in the future & $\%$ & $\begin{array}{c}\text { No. } \\
\text { respondents }\end{array}$ \\
\hline Voluntary & 17.0 & 24 \\
\hline Cost covering & 27.0 & 38 \\
\hline Mean of marketing & 17.7 & 25 \\
\hline As a viable activity & 22.7 & 32 \\
\hline Decrease/quit EDF activity & 7.1 & 10 \\
\hline Don't know & 2.8 & 4 \\
\hline Other & 5.7 & 8 \\
\hline No answer & 0.0 & 0 \\
\hline Total & 100.0 & 141 \\
\hline
\end{tabular}

Source: As Table 1.

Finally, issues regarding the EDF activity are given in Table 10. As mentioned earlier, the educational activity at the farm increases the risk of spreading highly contagious diseases among livestock due to the open door policy for visitors.

Table 10 clearly indicates that this is the biggest issue that EDF operators face, and it poses a deep dilemma for the sustainable development of the educational activity. Prevention measures are not only the responsibility of individual farms, but also that of the public sector, especially those in charge of the quarantine office. Thus, support measures for quarantine will become more essential in the future. The next greatest issues were related to on-farm facilities, i.e. toilets and lecture rooms. This is because inadequate toilet facilities can hamper the smooth implementation of the educational program, especially for a group of school children. A lecture room is also effective for enhancing the educational program given by operators. 
Table 9: Attitudes toward EDF service charge.

\begin{tabular}{|c|c|c|}
\hline Levying service charge & $\%$ & $\begin{array}{c}\text { No. } \\
\text { respondents }\end{array}$ \\
\hline Whole service & 29.8 & 42 \\
\hline Partially & 24.1 & 34 \\
\hline No charge & 33.3 & 47 \\
\hline Variable & 7.1 & 10 \\
\hline Other & 3.5 & 5 \\
\hline No answer & 2.1 & 3 \\
\hline Total & 100.0 & 141 \\
\hline Measures toward implementing a service charge & Point & No. \\
\hline (5-scale evaluation) & 4.0 & 121 \\
\hline Quality improvement & 3.9 & 122 \\
\hline PR activity & 3.5 & 119 \\
\hline Financial assistance & 3.3 & 118 \\
\hline Utilization of social media & 3.3 & 118 \\
\hline As collateral service with selling product & 3.3 & 118 \\
\hline Cooperation with mass media & 3.0 & 117 \\
\hline Partnership with travel agency & 2.9 & 116 \\
\hline NPO & 2.5 & 122 \\
\hline No charge policy & 1.0 & 3 \\
\hline Other & & \\
\hline
\end{tabular}

Source: As Table 1.

Table 10: Issues of EDF activity.

\begin{tabular}{|c|c|c|}
\hline Issues of EDFs (5-scale evaluation) & Point & $\begin{array}{c}\text { No. } \\
\text { respondents }\end{array}$ \\
\hline Epidemic prevention & 4.7 & 138 \\
\hline Toilet & 3.9 & 104 \\
\hline Lecture room & 3.9 & 107 \\
\hline Knowhow & 3.7 & 125 \\
\hline Labour & 3.5 & 132 \\
\hline Making compatible dairy and educational activities & 3.3 & 133 \\
\hline Educational material & 3.3 & 131 \\
\hline Development of educational program & 3.1 & 129 \\
\hline
\end{tabular}

Source: As Table 1. 


\section{Conclusion}

Farms have been attracting a growing number of visitors from school and consumers in general. The present survey has shed light on the educational service that the EDFs offer to visitors and has investigated the experience and attitudes of EDF successors toward the educational activity, together with the issues that this younger generation has. To achieve this aim, differences between EDFs and ordinary dairy farms were compared by sending questionnaire surveys to both types of farm. The main findings were as follows.

EDF successors tended to have wider job experience, and longer and more varied job-training experience than their counterparts in ordinary dairy farms. In addition, female successors were more involved in EDFs than in ordinary dairy farms. These observations imply that EDF successors have a wider perspective and more extensive human networks from social learning opportunities, both of which are crucial aspects in the development of this emerging innovative educational service.

Through the educational activity, EDF successors gained satisfaction in terms of psychological reward and strengthened their identity as a dairy farmer. Nevertheless, the majority of EDF successors did not consider the educational service as an economically viable product, but rather a social behavior that offers benefit to the local community and society.

In the long term, levying a charge, rather than maintaining it as a voluntary service, will be necessary to make the educational activity viable. This is a step forward in enhancing the recognition of this service as a new social role that dairy farmers can play in a sustainable manner. Quality improvement was considered to be an important measure for this purpose. Consequently, there should be a training program not only for improving technical skills to enhance the educational program, but also for generating a positive attitude to raise viability. Finally, for the younger generations of farmers, it is effective and necessary to provide more opportunities for job-training involving wider aspects of dairy farming.

\section{Acknowledgements}

The questionnaire survey for this research was financed by the Japan Dairy Council and the subsequent analysis was funded by Grants-in Aid for Scientific Research No. 24658191, Japan Society for the Promotion of Science (JSPS).

\section{References}

[1] Graham, B., The work of farming and countryside education (FACE). $J$. Royal Agricultural Society of England, 165, pp. 1-8, 2004.

[2] Gatward, G., 'The society's charitable activities', Journal of the Royal Agriculture Society of England, 168, pp. 1-8, 2007.

[3] Canavari, M., Huffaker,C., Mari, R., Regazzi, D., and Spadoni, R., 'Educational farms in the Emilia-Romagna region: their role in food habit 
education', Symposium on 'Food, Agri-Culture and Tourism', University of Göttingen, December 15, pp. 1-24, 2009.

[4] Moore, R.C., Children gardening: first steps towards a sustainable future, Children's Environments, 12(2), pp. 222-232, 1995.

[5] Ohe, Y., Evaluating jointness of multifunctional agriculture: the educational function of dairy farming in Japan, Environmental Economics and Investment Assessment, ed. K. Aravossis, C.A. Brebbia, E. Kakaras \& A.G. Kungolos, WIT Press: Southampton, pp. 337-346, 2006.

[6] Ohe, Y., Emerging environmental and educational service of dairy farming in Japan: dilemma or opportunity? Ecosystems and Sustainable Development VI, ed. E. Tiezzi, J.C. Marques, C.A. Brebbia \& S.E. Jørgensen, WIT Press: Southampton, pp. 425-436, 2007.

[7] Ohe, Y., Evaluating Internalization of Multifunctionality by Farm Diversification: Evidence from Educational Dairy Farms in Japan. $J$. Environ. Manage. 92, pp. 886-891, 2011.

[8] Ohe, Y., Operators' attitudes on educational tourism in agriculture, Pineda, F.D. \& Brebbia, C.A. eds. Sustainable Tourism V, Southampton: WIT Press, pp. 273-286, 2012. 